promising seem to be the organising of district panels of suitable lecturers, the inclusion of provisional science courses in the programmes of classes, and propaganda to encourage interest in the study of science, by printed leaflets and by peripatetic lecturers capable of interesting popular audiences. Two interesting "general recommendations" are added : that there should be "a rapid and progressive improvement in the supply of films and slides applicable to science teaching ", and that for this purpose " the Association should investigate the possibilities of the setting up of a national organisation for the production and distribution of educational films ".

\section{The Science Museum during 1931}

The Report of the Advisory Council of the Science Museum of 1931 is the first issued since the Council was reorganised on lines suggested by the Royal Commission on National Museums and Galleries. With Sir Richard Glazebrook as chairman, the Council now includes three representatives appointed by the Board of Education, and twenty-six representatives of various scientific, technical, and industrial institutions. The Royal Commission also recommended that the Advisory Council should be assigned a more active part in the management and development of the Museum, and the adoption of this recommendation has already resulted in the appointment of a Standing Committee which will meet four or five times annually, and of three small sub-committees which are to report on the Scicnce Library, the development of the Electrical Engineering Section, and on an exhibition of pottery and porcelain manufacture. The Report contains details of the attendances, lectures, temporary exhibitions, acquisitions, and of the Library. It also contains a tribute to the late Sir Hugh Bell, who was chairman of the Advisory Council from 1912 until 1931, and to the Director, Sir Henry Lyons, and his staff. Among the acquisitions during the year are the apparatus used by Sir William Ramsay in his work on the rare gases of the atmosphere, the fine collection of optical instruments, numbering nearly 600 , given by $\mathrm{Mr}$. T. $\mathrm{H}$. Court, and the cinematographic apparatus invented in 1887-89 by Louis Augustin Le Prince, who dis. appeared while travelling in France in 1890.

\section{Safety in Mines}

The Safety in Mines Research Board has just issued Paper No. 74, which contains an account of an important conference on safety in mines held at Buxton last year. There seems no adequate reason why information about this important conference should have been so long delayed, though there may have been difficulty in getting the authors of the various papers to correct their contributions. The meeting derives its great importance from the fact that it was the first international conference of this kind. In addition to the British representatives, there were delegates from Belgium, France, Germany, and the United States. A number of important papers on mining explosives were read, and proposals were made for future international meetings, subject to ratification by the organisations concerned-a ratification which, we presume, will certainly be forthcoming. Perhaps the most important of the suggested future arrangements was that "Periodical meetings of the directors of research shall be arranged at each research station in rotation". This arrangement would thoroughly ensure the international character of future conferences, and it is a most welcome sign that the question of safety in collieries is for the future to be treated as an international question and not as one possessing local interest only.

\section{Geodetic Surveying in the United States}

ThE annual report of the Director of the United States Coast and Geodetic Survey for the year 1930-31 (Washington, 1931, 45 pp., 60 cents) describes briefly the wide range and large extent of the activities of this important and progressive organisation. It has as a frontispiece a photograph of the new surveying vessel (one of several possessed by the Survey) Hydrographer, commissioned in March 1931, and fully equipped with sound-ranging apparatus for depth-surveys ; sound-ranging is also used for locating the position of the ship from the shore at the time of each depth-measurement. The use of these methods has greatly increased the rapidity of the coastal survey work. The control survey work on land has also been rendered much more rapid and less expensive by abandoning the erection of the large wooden towers formerly used in flat or rolling country, at points about ten miles apart, to enable the observers to see across such distances over intervening trees and other obstructions. These towers were often 100 feet or more in height, each being double, so that the observer could walk on the outer platform, unconnected with the inner tower carrying the instrument. They contained large quantities of material, used once only, and required much time to erect. They are now replaced by portable steel towers, which can be erected by five men in less than a single working day, and used many times, their transport from one place to another being made by trailer trucks. An improved and smaller theodolite has also been devised and brought into use.

\section{Czechoslovakian Contributions to Science}

THE scientific communications to the Czech Academy of Sciences during 1928 and 1929 have now been published in French or English in volumes 29 and 30 of the Bulletin International of the Academy. Among the papers presented are several by Dr. F. Nermejc dealing with his palæobotanical investigations on some quaternary deposits in the district around Ružomberok in Slovakia. Dr. R. Kettner has made a similar study of the geological formations in the Hron Valley, and Prof. Ulrich describes the minerals variscite and barrandite from Třenice and also a Slovakian rutile. Dr. J. Hahn's account of the life history of Monocystis Mrazeki is illustrated with some fine photomicrographic plates, whilst M. Uher's communication dealing with the genesis of nerve elements cultivated in vitro is similarly illustrated. Dr. $O$. Jirovec has succeeded in observing and recording on a coloured plate some twenty stages in the nuclear 